\title{
Glass Trade Beads from Reese Bay, Unalaska Island: Spatial and Temporal Patterns
}

\author{
Barbara E. Bundy, Allen P. McCartney, and Douglas W. Veltre
}

\begin{abstract}
Unalaska History and Archaeology Project researchers excavated several thousand glass trade beads from an Aleutian longhouse at the Reese Bay site on Unalaska Island, Alaska. This paper provides a description of the beads, a discussion of their use by Russian explorers and Alaska Natives, and an analysis of the horizontal and vertical distribution of the beads within the longhouse. Comparison to other Alaskan sites revealed that the composition of the Reese Bay trade bead assemblage is consistent with occupation during the early Russian period. Several factors, both behavioral and depositional, created and affected the spatial patterning of the beads within the site: roof fall from the dismantling of the longhouse superstructure; periodic housecleaning by the residents of the longhouse; bead working techniques and location preferences; and changing status relationships within the longhouse. The spatial and temporal patterning of the glass trade beads from the Reese Bay site provides insight into the lives of the inhabitants.
\end{abstract}

\section{Introduction}

By the middle of the eighteenth century, Imperial Russia's search for fur led to the shores of the New World. In 1741, Aleksei Chirikov, secondin-command of the Bering expedition, returned to the Russian mainland with hundreds of pelts, including 900 sea otter skins (Berkh 1974:1). His cargo touched off a Russian "fur rush" to Alaska that ran from 1743 until the sale of Alaska by Russia to the United States in 1867 (Gibson 1976:viii). The occupation of Alaska began in the Aleutians and moved steadily eastward. It was generally characterized by hos- tility toward Native groups, although contact situations also included intermarriage and mutually beneficial trade relationships (Gibson 1976:8).

This paper examines the early Russian contact period through a case study of the glass trade beads recovered from the Reese Bay archaeological site on Unalaska Island in the eastern Aleutian Islands (Fig. 1). The bay is located on the north end of the island, northwest of Unalaska Bay. The Reese Bay site (UNL-063, Fig. 2) is situated on a spit formed 3,000-5,000 years ago (McCartney et al. 1988) and consists of two large multi-family longhouses from the early

Barbara E. Bundy, Department of Anthropology, University of Oregon Eugene, Oregon 97403

Allen P. McCartney, Department of Anthropology, University of Arkansas Fayetteville, Arkansas 72701

Douglas W. Veltre, Department of Anthropology, University of Alaska Anchorage, Alaska 99508 


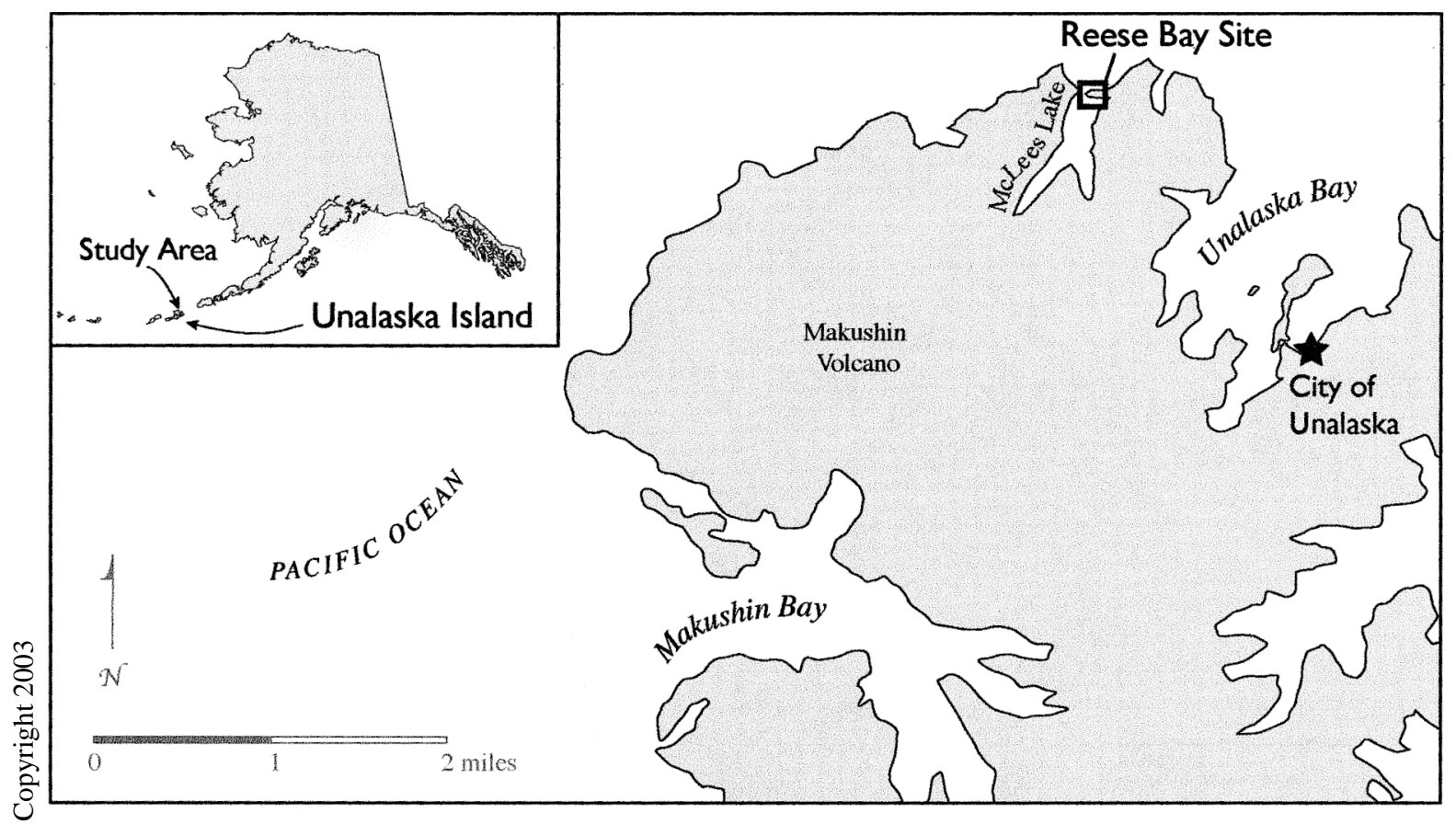

Figerie 1. Unalaska Island (north portion), showing location of Reese Bay site.

ก

contäoct period, an older midden, and smaller houres of an indeterminate period (McCartney and Lonhouse 2 was tested in 1986 and partially excivited in the late 1980s by the Unalaska Historfand Archaeology Project (McCartney et al. 198. 1990).

I More than 2,000 glass trade beads were recovहुred from the longhouse excavation. This beas collection is used to consider different questions about the community at Reese Bay. First, the occupation of the site in historic times can be dated by seriating the beads, a technique successfully applied in other areas of Alaska (Crowell 1994). Second, the distribution of the beads within the site may reflect Native social structure during the early Russian contact period, especially in terms of gender and status. Understanding changes in bead use through time provides insight into how Alaska Native communities adapted to both the stresses and the opportunities of Russian contact. With those goals in mind, the ethnohistorical documentation of the glass bead trade in the early Russian period is reviewed, and the composition and distribution of the Reese Bay trade bead assemblage is compared to historically reported patterns of bead use.

\section{Trade Beads and Historical Archaeology}

Russian traders and explorers left few descriptions of traditional Unangan and Eskimo cultures as they existed at the time of contact, although by the nineteenth century a few clergymen were writing detailed accounts (Black 1988). The accounts, like many colonial documents, are difficult to interpret. Even with the best of intentions, first-time observers of a culture can easily form misconceptions that are reflected in text and illustrations, a process Grumet (1995:7) called “creative misunderstanding." It falls to archaeologists to clarify the history of this important era of upheaval and culture change.

Archaeological data have much to offer in the search for a balanced history of the European occupation of North America. Trade bead analysis can clarify a number of theoretical issues for several reasons. Beads have played an important role in European trade with local groups all over the world. This ubiquity provides an excellent base for comparing European and Native American relations at different times and places. Also, glass trade beads can be "a reliable dating index" if archaeological and ethnohistorical sources are combined (Spector 1976:17). Woodward (1965) noted that trade bead preferences among Native groups 


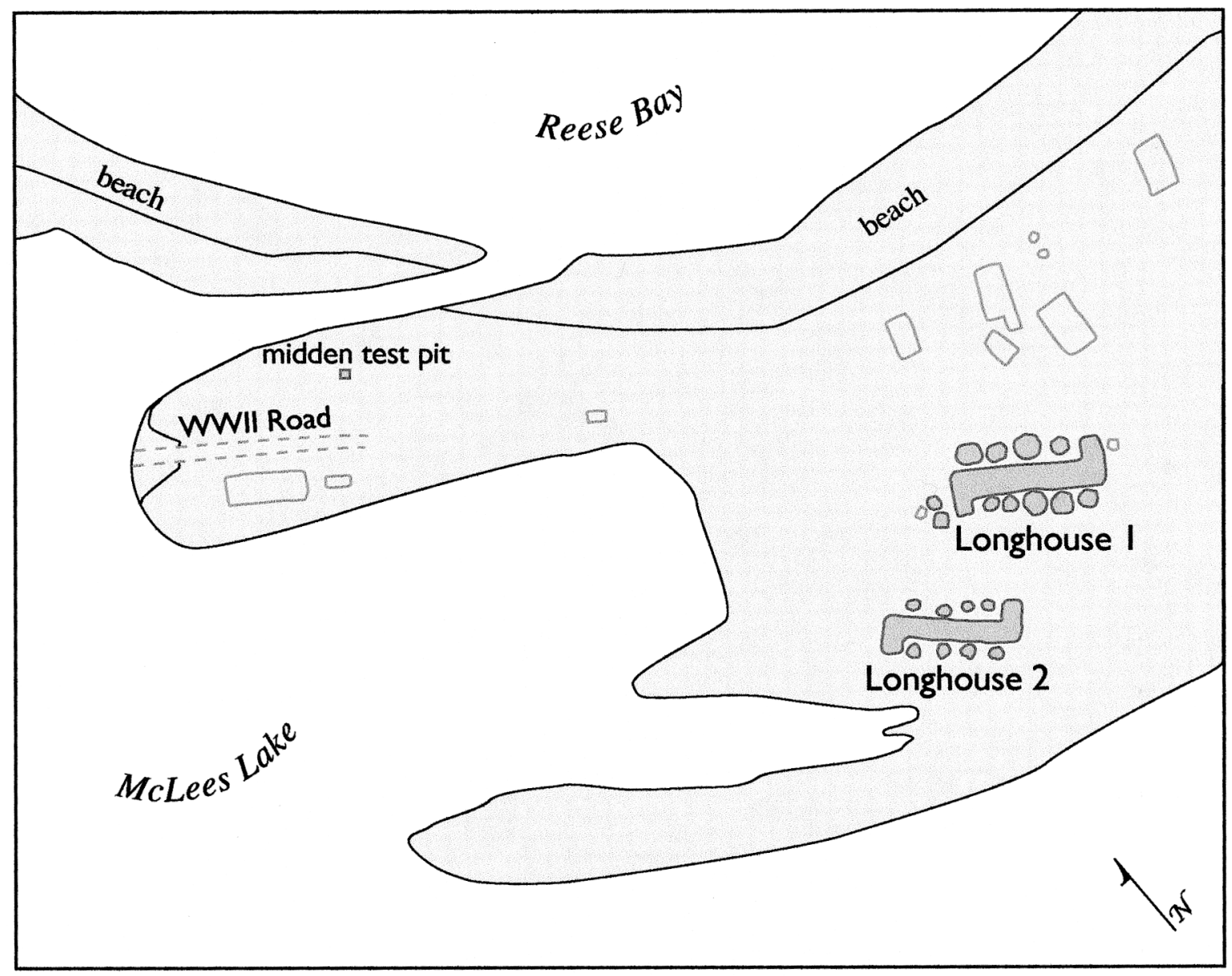

Figure 2. The Reese Bay site (UNL-063), from McCartney et al. (1988:5).

often changed quickly, making time-definition rather precise. In fact, trade beads have been successfully used as diagnostic artifacts for determining dates of occupation and sources of trade goods (e.g., Crowell 1994; Mitchem and Leader 1988). Finally, beads often functioned differently in European economies than in Native economies. The role of beads (and other ornaments) has often been likened to that of coin money in a traditional Western market system because they are "roughly commensurable and highly portable" (Graeber 1996:4). Their use by Native groups, however, was probably also influenced by the importance of status, rules, preferences regarding ornamentation, and perhaps the individual history of the beaded objects (Woodward 1965:18). All of these considerations dictated the value of the beads and the universe of possibilities for their distribution (Graeber 1996). Finally, beads are easily lost, mitigating the effects of curation of artifacts during site use and abandonment. Given these qualities, it should be possible to discuss spatial patterning of beads with reference to social and economic structure in rapidly changing and adapting societies.

Glass trade bead studies have been approached in many different ways, depending on the research goals of the project. Typical interests are: dating site occupation; determining the manufacturing origin of the beads; understanding the availability of beads and the preferences of bead consumers; discussing the use of beads during site occupation; and inferring the causes of bead loss and disposal (Francis 1994). Bead use and loss patterns reflect consumer preferences, bead availability, and other rules of ownership and ornamentation. Archaeological patterning may also be the result of beaded-item manufacture and related issues like the availability of beading materials (e.g., fine needles, thread) and visibility. Spector (1976) suggested that bead researchers 
use both ethnohistorical and archaeological data to accurately classify and describe beads, and to understand how they were perceived and used by Native and European groups.

\section{The Aleutian Islands}

\section{Climate and Geography}

The Aleutian Islands begin with Unimak Island just west of the Alaska Peninsula and extend about 1,100 miles to Attu Island. The windswept islands are home to a diverse marine environment (Pielou 1991:130). Sea otters, sea lions, and hair seals are present year-round, as are many intertidal shellfish species due to the absence of winter ice (Murie 1959). Whales, fur seals, migratory birds, salmon, and plant foods are available seasonally (La@ghlin and Aigner 1975). Halibut and cod are present year round, but are more easily obtained durīng certain seasons when they move inshore. Theơmany bays and inlets that mark the shores of the islands increase the amount of coastline availablङ્રీand provide sheltered landings for both humans and their prey (McCartney 1984). Although it aypears inhospitable, the Aleutian environment has marÉcommunity for over 8,000 years (McCartney 198菏; McCartney and Veltre 1999). כू

\section{Thè् Unangan People}

Mosit of the historical information about Unangan culforre during the second half of the eighteenth cen Imprial employees to the Russian government (Lia unova 1996:133). It was not until the first half of the nineteenth century that Bishop I. Veniaminov ([1840] 1984) made the first effort to comprehensively document Unangan life (Liapunova 1996:31). Several researchers have gleaned the following description of early contact-era Unangan culture from early reports, Veniaminov's works, and archaeological data.

The Aleutian cultural tradition at the time of European contact, and long before, was characterized by a very effective focus on marine resources (Laughlin 1980; McCartney 1984). Seals, whales, otters, and occasionally walrus, were hunted at sea (Liapunova 1996:89). Although Russians claimed that "the love of the Aleut for catching sea otters surpasses any description” (Russian Naval Officer, quoted in Gibson 1976:8), Laughlin (1980:42) suggested that the animals were infrequently hunted prior to Russian demands for their pelts. Young boys trained rigorously to perfect their endurance and hunting techniques, and Europeans never matched the efficiency and skill of Unangan sea mammal hunters (Laughlin 1980:29, 44). Other marine resources, like fish, birds, and shellfish, were also collected (Jochelson 1933:51; Lantis 1984). Plentiful resources and wet weather ensured that "not much food was stored except for the festivals" (Lantis 1984:176).

Unangan socio-political organization at the time of Russian contact resembled that of other northern coastal groups, including Alutiiq and Tlingit (Lantis 1984). Like the Tlingit, Unangan society was divided into three groups: elites, commoners, and slaves (Liapunova 1996:138-139). The elite group consisted of toions (chiefs), acting as household heads, and their direct descendants. A toion oversaw kin-controlled hunting grounds and enforced behavioral norms, but "it may be that kin membership was separate from inheritance of office or privileged position" (Lantis 1984:176). Laughlin (1980:58-59) noted that household heads were also expected to be unusually strong and successful hunters. Thus, while status was indicated by descent, it was not ensured.

Eastern Aleutian Islanders lived in semisubterranean longhouses that Russians called barabari or yurts (Laughlin 1980:50; McCartney and Veltre, in press.). A longhouse contained several families who were related in a variety of ways in that "rules of residence did not seem to be strictly enforced" (Lantis 1984:176). Veniaminov ([1840] 1984) reported that residence within the longhouse was determined by status, with the highest-status individuals living at the east end and others continuing in descending order. $\mathrm{Nu}-$ clear families had living and sleeping space along the walls of the structure, and side rooms were used for storage or additional living space (Veniaminov [1840] 1984:262). Assessments of how many people lived in a single longhouse vary, but a fairly conservative estimate might be 40 residents (Laughlin 1980:50).

Unangan life was patterned not only by the demanding environment, but also by strong cultural traditions. Understanding how these traditions changed as Unangan people adapted to Russian contact is central to historical archaeology and ethnohistory in the Islands.

\section{Russian America}

Russian actions in the New World were determined by economic goals and restrictions, environmental constraints, religious convictions, and the cultural traditions of Russian and Native 
groups. These factors make the history of the Aleutian Islands after Russian contact unique in many respects, but also similar to other contact situations. During the eighteenth century, the future of any European country rested on its colonial possessions. Strongly centralized monarchies competed for control of lucrative new territories, in the hopes that the exploitation of new lands would lead the colonial power to a strong position in the European economy (Pagden 1995:66-67). Russia, long dismissed as an economic backwater, was especially eager to become a major financial force in Europe

(Dmytryshyn et al. 1988). The high demand in the West for fur- "soft gold"- - provided the opportunity the Russian government sought.

Alaska, however, was problematic for Rus¿̊ sian fortune-seekers. Russian sailors, often in makeshift vessels, were ill-prepared for the violent Sorms and winter ice of the Bering Sea

oे(Dmytryshyn et al. 1988:xl; Makarova 1975:38).

Transportation in the new colony also proved dif-

ธิ ficult, and Native resistance in some areas was

fierce. Provisioning of explorers, and later settlers, was a constant problem (Gibson 1990). By the 1770s, Russians also faced competition from the of English, French, and Spanish in the New World, a $\overrightarrow{\mathrm{s}}$ situation that became a drain on already scarce reכ્ossources (Gibson 1990). Despite these daunting obâstacles, many Russians found the lure of Alaska E irresistible. As the trickle of Russian merchant voyages and government-sponsored expeditions g became a flood, Alaskan Natives were forced to odopt a variety of survival strategies.

\section{Native-Russian Relations in the Early Contact Period}

Unangan resistance, violent and non-violent, is well documented throughout the Russian occupation (e.g., Berkh 1974:33-34; Dmytryshyn et al. 1988). It is likely that the Unangan people were quickly subjugated by Russian demands due to their isolation, as well as lack of access to firearms (Dmytryshyn et al. 1988).

Russian Imperial policy ostensibly encouraged, even demanded, friendly relations with indigenous people. A report by a Siberian official authorizing Ivan Bechevin's 1760 voyage clearly states that any crewman "is to be obligated, under penalty of death ... not to cause any harm or even the slightest resentment among the inhabitants of the island who are iasak [tribute-paying] subjects" (as quoted in Dmytryshyn 1988:204). However, it was reported in 1776 that Bechevin's men "com- mitted indescribable abuses, ruin and murder upon the natives there [the Aleutians]" (Zubov in Berkh 1974:28). Government agents were sent to the colonies to investigate reports of abuse on several occasions as the Imperial Government struggled to control the fur trade in the 1780s (Dmytryshyn 1988). However, practices and attitudes supported by the government hindered the achievement of that goal. Until 1788, the Russian government required that inhabitants of land claimed by the government pay iasak, usually in furs (Gibson 1969:31). Voyagers were required to keep records of tribute paid, and upon their return to Russia these "iasak books" were scrutinized (Dmytryshyn et al. 1988). This practice must have encouraged promyshlenniki [Russian fur-hunting sailors] to collect tribute by whatever means necessary. Although the practice of giving gifts-often trade beads-in return for iasak was fairly common, the gifts were specifically meant to create a feeling of indebtedness that encouraged payment in the future (Khlebnikov 1994:240). There was also significant pressure from the government and private companies for expeditions to return with many furs, which contributed to forced labor and other mistreatments.

Additionally, Russian officials regularly referred to Native inhabitants as savages and heathens (as quoted in Dmytryshyn 1988). Gifts given as trade goods or in exchange for iasak were considered trinkets and worthless baubles, proof that Native people were unable to judge true value. This perception of superiority surely encouraged and excused abuses by Russian promyshlenniki. Thus, although the Imperial Government nominally discouraged mistreatment of Alaska Natives and Siberians, its own social philosophy and economic policies exacerbated the problem (Bundy 1998).

Thoughtlessness, misunderstandings, and outright cruelty on the part of the Russians led to the rapid depopulation of the Aleutians. Many hunters were killed on forced sea mammal hunts. In the last decade of the eighteenth century, some were taken to other Russian-held areas, never to return to their families (von Langsdorff 1993:13-14). Also, those who remained were forced to focus their efforts on obtaining sea otter pelts to the exclusion of important food sources (Dmytryshyn et al. 1988). The absence of hunters led to food shortages in Native communities, food poisoning from eating rotten beached carcasses (Dmytryshyn et al. 1988), and a shift in the subsistence economy to focus on "resources obtainable without their male hunters present” (Veltre 1990:179). Diseases introduced by Europeans also contributed to population 
loss and weakened survivors. Population decrease, as well as the Russian desire to consolidate settlements within reach of their insufficient staff, led to the resettlement of entire villages (Veltre 1990).

European interference in Native American settlements often led to unforeseen social disruption (e.g., Rollings 1992:154). Europeans (including Russians) preferred to identify one man as the sole leader of a community, and favored him in trade and political dealings. In Russian America, single men were encouraged to marry Native women, allowing those women greater access to European goods. These two practices created a class of high-status men and women who acted as "middlemen, or brokers, between the two cultures" (Veltre 1990:180). The trade goods accumulated by these middlemen may be found in the hig as in Russian dwellings.

Changes made to settlement patterns during the ussian period altered the issue of status and residence. Christian beliefs favored the European style single-family unit over household-based or polyggamous arrangements (Veltre 1990). Veniami़ov ([1840] 1984:264) wrote that in 1805 the Rus îian-American Company employee Rezanov orderegd that Unalaskans build above ground singlefamidy dwellings, effectively ending communal longhouse use. Together with severe population rediction, this significantly changed settlement pattirns. The upheaval in Unangan life caused by Rusigian occupation was present very early in the conf period, and surely impacted communities likegु̆he Reese Bay village.

\section{Thể Chronology of Contact in the Unalaska Area}

Unalaska Island is mentioned in many early Russian accounts, and Reese Bay itself in a few of those (McCartney et al. 1988). Russia claimed Unalaska Island in 1753 when Bashmakov "discovered" the region (Berkh 1974:14-15), but the first contacts with inhabitants were not reported until at least 1758 (Black 1991). A history of early contacts is provided by Black (Black 1991; Black and Liapunova 1988; McCartney et al. 1988) and is summarized here. Stepan Glotov made the first recorded contact in 1761-although there may have been earlier Russian landings on the island. Glotov apparently enjoyed "amicable relations and trade until his departure in May 1762" (McCartney et al. 1988:34). In 1763, however, the crews of the Sv. Gavriil and the Sv. Vladimir dis- carded this peaceful precedent. The behavior of the men, which included beating, rape, kidnapping, and murder, later prompted an Imperial judiciary investigation. The brutality of this incident elicited an organized military response from Unangan people on Umnak, Unalaska, and Unimak islands. It is unclear if such a large alliance was a departure from previous precontact political interactions.

The first specific mentions of the Reese Bay site in Russian writings occurred between 1763 and 1766, when six different Russian vessels visited Unalaska Island. After this date, the degree of Russian-Unangan interaction is difficult to ascertain. McCartney et al. (1990:23) note that there was "a differential concentration of Russian shipping in specific areas of the Aleutian archipelago and around certain favored harbors.” Reese Bay was apparently not one of these harbors. Although there is some mention of a trading post at neighboring Captains Harbor by the mid-1770s (Gibson 1976:5), it is unclear how much contact the Reese Bay villagers had with a frequented port or permanent settlement.

Between 1763 and 1764 there were several armed conflicts between Russians and Unangan people. Inhabitants of Reese Bay (called Veselovskoe settlement by Veniaminov [1984:93]) are named specifically in these accounts. In one incident in 1765, 19 Reese Bay villagers were killed in a conflict with Solov'ev (Black 1991). Native military resistance was unsuccessful in the long run, and by the time of Captain James Cook's visit to the Aleutians in 1778, Russians were interacting with Native communities on almost all the islands. Thus, during the early period of Russian occupation, Native-Russian relations varied from fairly amiable trade to outright warfare.

Billings estimated the population of the Reese Bay village in the 1780s to consist of about 30 adult males and their dependents, a number already diminished from the first estimates (Titova 1980). According to Veniaminov's estimate ([1840] 1984), by 1824 only 15 people were living at the site. Von Langsdorff (1993:13-14) and other observers attribute the rapid population decrease in the Aleutian Islands in general to great losses of men in forced hunts for sea mammals and stressful living conditions for the remaining villagers. Accurate dating of the site is essential in reconciling historical accounts and the archaeological record. In this tumultuous era, the presence and distribution of trade goods are significant. Trade goods do not just indicate acculturation in the form of the 
gradual adoption of a market economy; rather, the distribution of non-local items was the end product of a multifaceted relationship.

\section{Glass Trade Beads in the Aleutians}

Three aspects of trade bead research are relevant to the study of social reorganization in the Aleutians: manufacture and typology; historic reports of use; and frequency and distribution in archaeology sites. To address these topics, we establish a consistent descriptive typology and examine the historical bead trade before discussing frequency and distribution.

\section{Bead Nomenclature, Typology, and ڤ̊ Manufacture}

Fom the earliest archaeological reports of trade beads to the present, typology has been problematic. Beads are named in several different ways, $\rightarrow$ and nomenclature is generally not consistent over کิ time and across regions (Sprague 1985). Localized i manufacturers and traders had their own systems of classification based on size and/or manufacturing technique, and "the collector of beads in our ธี own times has added to the confusion by calling $\overrightarrow{0}$ beads by local terms which outside that area have E⿱ tompts at bead terminology tended to be broadly descriptive rather than exact, but by the 1970s several objective classification systems had been proposed (e.g., Karklins 1982; Kidd and Kidd 1970; Stone 1970). These typologies are based on "formal, physical properties of glass beads which reflect manufacturing processes" (Spector 1976:20).
There is no hierarchy or value assessment implicit in the language, and indeed most of the typologies use letters and numbers to represent bead types. However, more recent studies use both descriptive language and a type number for more detailed reference (e.g., Crowell 1997), a precedent that will be followed here. The 2,266 Reese Bay beads analyzed here were coded by Scott (1990) following the Kidd and Kidd (1970) system.

Bead color description has been challenging for archaeologists. Even in similar beads, color may vary because "the purity of the coloring chemicals was not well controlled" (Spector 1976:22). Recently several bead researchers have advocated using Inter-Society Color Council National Bureau of Standards (ISCC-NBS) Color Centroid Charts (1955), which render colors comparable even in text description. Many of the Reese Bay beads were assigned Centroid Color Chart numbers by Scott (1990). These standardizations make the Reese Bay data comparable to those from other sites in southern Alaska (Table 1).

Several researchers have discussed at length manufacturing processes and the related nomenclature (Kidd 1979; van der Sleen 1973; Woodward 1965). The techniques relevant to the Reese Bay beads will be summarized here to define the terms used in bead descriptions. There is an essential division between drawn (hollow-cane) beads and wire-wound (mandrel) beads. Drawn beads were cut from a long, thin tube of glass (the hollow cane). The glass was drawn out of a furnace on a rod, and shaped while still molten. The cane was formed by introducing a bubble to a mass of molten glass in which two rods have been inserted. At this point, the original glass may have

Table 1. Reese Bay bead colors and the associated Centroid Chart numbers.

\section{Color Group}

White

Light and Greenish Blues

Reds

Yellows

Greens

Dark and Purplish Blues

Very Dark Burgundy (Appears

Black)

Ambers (Orange and Brown)

Clear

Undetermined or Multi-colored

\section{Associated ISCC-NBS Color Centroid Chart Numbers}

263, 92 (yellowish white, one bead)

$168,169,171,172,173,175,180$

6,40

$68,72,83,85,86,87,89,90,91,94,99,102$

136, 137, 141, 144, 145, 146, 162

176, 183, 184, 185, 194, 196, 197, 204

267

Number in Reese Bay Bead Collection

1199

748

184

34

30

29

15

$54,55,59,62,76$

10

N/A

N/A
10

7 
been dipped in another color (or colors) of glass to form a multi-layered bead. The cornaline d'Aleppo (a red bead with a clear, green, or white center), common in Alaskan assemblages, was manufactured in this way. Two people then pulled the rods apart, often to considerable length. The finished canes were laid on wooden racks to cool. Often, the beads were polished and their sharp corners rounded off by agitating them in hot sand. Manufacturers usually sorted drawn beads in sieves, strung them, and sold them by size in bundles of 12 (or more) strings.

In the Kidd and Kidd system, drawn beads are divided by shape, decoration, and size. First, beads that have been rounded are separated from non-rounded beads, and multi-layered beads are separated from single-layered, resulting in four gro@्रिps. These are further subdivided by the existenes and type of surface decoration, and then by the $\cdot 0$ verall shape of the bead.

ôWire-wound beads (sometimes called necklace beads) were produced quite differently. A prema glass rod was heated over a fire until soft and thenु-wound around a stiff wire called a mandrel. Thẹpeads could be pressed into a mold or rolled alor sign's could be made by using rods of several colors to form the bead, or by "drawing" on the still-hot beafiowith thin lines of glass and possibly drawing a wire through those to make floral or other designs. After several beads had been wrapped arotind it, the mandrel was set aside to cool. The beass were then shaken from the mandrel. Wirewold tent reqginire a furnace, they could be produced by a cottage industry. In the Chinese wire-wound bead industry, individuals bought glass rods from a factory and then sold the finished beads back to the factory for payment and more glass (Miller 1994:12).

Wound beads are much harder to classify than drawn beads because they are made individually and are "capable of almost infinite variation" (Kidd and Kidd 1970:49). However, they are often divided into simple categories based on shape and decoration. Single-color undecorated beads are separated from plain, shaped beads and from decorated beads (which may or may not be shaped). Both shaped and shaped-and-decorated beads are subdivided by appearance. Kidd and Kidd (1970) offer color plates for both wound and drawn beads that represent further numbered divisions, but the use of color charts seems to have replaced this final classification.
Almost all bead researchers agree that classification systems are not an end in themselves, but an analytical tool by which "comparison of various assemblages will reveal cultural and/or temporal dynamics" (Spector 1976:20). There were two main goals for the classification of the Reese Bay beads, to ensure that the assemblage is standardized and comparable to other collections, and to provide a basis for comparing spatial and temporal distribution of different types of beads within a house. Historical references to different bead types and the preferences of Russians and Alaska Natives make a logical starting point.

\section{Local Bead Names in Alaska}

Europeans in the Aleutian Islands make reference to beads by several different names. Russians most often use the terms bisera (singular biser) and korol'ki (singular korolek), which many believe refer to small drawn beads and larger wound beads, respectively (Crowell 1997:177). However, there are some apparent exceptions and inconsistencies in different accounts. It can be difficult to find sources in the original Russian, but several translators have used "glass beads" for bisera and "corals" or "large beads" for korol'ki (e.g., Khlebnikov 1994:4, 56, 122). The fact that korol'ki are often listed by number (although occasionally by a volume measure), while bisera are listed by a measuring unit (sazhen, which refers to length of the string), suggests that korol'ki were larger (Anonymous 1988 [1789]; Khlebnikov 1994:240). There are exceptions to this interpretation as well. Khlebnikov (1994:56) noted that Alaska Natives trading in Sitka "willingly receive light blue and red beads, large blue and small clear green korol'ki ..." indicating that some korol'ki are small beads.

It is tempting to speculate that some exceptions occur when the word korol'ki is used to designate color instead of size or type, much the same as "amber" or "coral" in modern English. In a modern Russian dictionary, korral (coral) is defined not only as an oceanic species, but also as "a bright-red, pink, or white stone” (Ozhegov 1989). Korolek in the modern language refers to a type of small, bright-red bird, or a round ingot of metal (Ozhegov 1989). However, korol'ki are often identified as transparent, dark blue, sky blue, and green (Khlebnikov 1994:57), but apparently never (or rarely) as red or pink. Thus, the connection with color suggested by the modern words is not supported by ethnohistorical descriptions. Although Unangan people likely had their own 
names for different bead types, these have not been recorded.

\section{The Arrival of Beads in the Aleutians}

Glass trade beads, as mentioned earlier, are a good chronological marker because styles change so quickly. How and why bead assemblages changed in the last decades of the eighteenth century in the Aleutians are crucial issues in assessing the meaning of the Reese Bay beads.

Alaska Natives in Russian America acquired beads in several different ways. Beads were sometimes given as gifts, as Europeans often offered trade goods on meeting local inhabitants to secure good relations. Chirikov ([1741] quoted in Dmytryshyn 1988:144-145) instructed his crew §ิ members who were going ashore on a previously unknown Aleutian island and might encounter Notives to "show them friendship and give them ôsmall presents" because the Russians hoped to gain information about the islands. Later, friend$\widehat{\delta}$ ship gifts were used to facilitate trade. Klichka స̂. ([1779] quoted in Dmytryshyn 1988:263) reported that the crew of the Sv. Vladimir successfully established friendly relations with the inhabitants of Unimak Island by giving "Cherkassian tobacco, various colored beads, ङ્ळopper kettles, shirts, and sealskins.” However, at the promyshlenniki for the most part destroyed E those peaceful relations by using other tactics, $\Phi$ detrimental to Native communities, to get what Ð they wanted.

Russians used gift giving with other coercive measures, like hostage taking, to force Native assistance. Krenitsyn and Levashev [1771] observed that in the Fox Islands, promyshlenniki:

... try to take hostages, children from that island or nearby islands. If they cannot do this peacefully they will use force. Once this is done, they issue traps to the natives to use to take foxes. They give the natives seal and sea lion hides called lavtaks, which the natives use to cover their baidarkas, and they also give glass beads, goat wool and small copper kettles. The natives become so indebted to the Russians that all the while the Russians are on the island the natives must provide them with fish and edible roots. (quoted in Dmytryshyn 1988:245)

Beads and other goods were also used to encourage allegiance and loyalty to Russians, and to soften demands for tribute. Khlebnikov (1994:240) cited a document from Attu Island that records a gift of “. . . 1 dagger, 356 korol'ki [large beads] of different colors-122 white, 158 light blue, 76 light colored-one funt red, one-half funt light blue, one funt yellow, and one-half funt green beads ..." made to a local toion. The document admonished the toion that he was ". . . commanded to accept the items shown and ordered that you should always be aware of the favor you have received" (Khlebnikov 1994:240). Empress Anna Ivanovna (quoted in Dmytryshyn 1988:117) ordered explorers to give local inhabitants "small gifts in the name of Your Imperial Highness when they pay their iasak." These offerings were more like exchanges for other goods and services than goodwill gifts.

Outright trading of European goods in exchange for furs was uncommon in the Aleutians. Unangan people were compelled, through hostagetaking and outright force, to accept whatever was proffered in return for furs. Coxe (1780:265) observed “. . . after obtaining from them [Unangan people] a certain quantity of furs, by way of tax, for which they gave them quittances; the Russians pay for the rest in beads, false pearls, goat's wool, copper kettles, hatchets, \&c.” Payment was not always satisfactory. An unidentified Unalaska Native ([1789] quoted in Dmytryshyn 1988:369) complained to Russian government inspectors that promyshlenniki “. . . send us out to hunt against our will and force us to provide food and do domestic work without pay. From Cherepanov's company we receive in exchange for each sea otter pelt either a kettle, shirt, knife, kerchief, a tool to make arrows, ten strings of coral or five, six, or ten tobacco leaves and a handful of beads." Thus, in the Aleutians, beads were initially given as gifts to forge ties or incur indebtedness, but later were forced upon islanders who were suffering more basic needs.

However, the fact that beads were not considered adequate compensation for goods and services does not mean that they were not valued. Many European reports note that Alaska Natives eagerly sought beads in some circumstances, especially in the first decades after Russian contact. During Glotov's voyage in 1763, several Kodiak Islanders: “. . . offered to barter fox-skins for beads. They did not set the least value upon other goods of various kinds, such as shirts, linen, and nankeen, but demanded glass beads of different sorts, for which they exchanged their skins with pleasure" (Coxe 1780:113-114). Cook found that in the Prince William Sound area, "a very great value" was set on large blue beads (Beaglehole 1967:1418).

Aleutian Islanders similarly favored glass beads and actively sought them for a time. Some 
types of beads had specific uses, and were highly desirable for that reason. Francis (1988) noted that beads were a prestige item in the Aleutians. Eventually, desire for tobacco, iron, alcohol, and other goods eclipsed demand for glass trade beads. Bead use likely also declined as traditional clothing and jewelry were replaced by European styles. An enormous number of beads, however, entered the Aleutian Islands before declining in popularity. In general, beads were very common and were used in a variety of ways.

\section{Glass Trade Bead Use by Unalaskans}

Bead use existed in the Aleutians prior to European contact. Amber and Dentalium shell beads, small carved bone or ivory figurines, and bird bea\&s were used as personal ornaments (Khlebnik@̂ 1994:122; Krenitsyn and Levashev [1771] as quo甪ed in Dmytryshyn 1988; von Langsdorff 199享16-17). Several European observers also reported the use of pebbles, bone, or ivory "cut like teethi" (Coxe 1780:257) which could refer to labrêtts, beads hung from them, or both.

¿ीLikewise, glass trade beads were used mostly

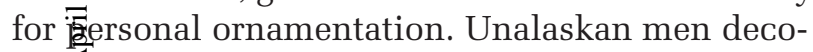
rated hunting hats with large blue wound beads,

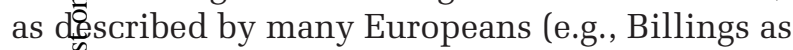

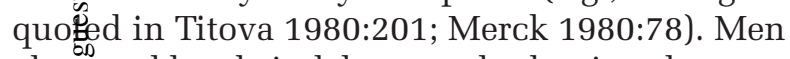
also: 1 used beads in labrets and other jewelry, apparently for feasting occasions. Krenitsyn and Levashe्धv (quoted in Dmytryshyn 1988:248) reported thaf "in good times when they are engaged in festiviteres they put beads and small bits of amber in the ears and between the labrets in the lower lip. Merck (1980:78) noted men wearing “a ring of gut string through the cartilage of their nose. Some glass garnets are strung on that ring." Men do not appear to have worn clothing decorated with beads or other ornaments.

Unalaskan women's clothing, on the other hand, was often heavily beaded with a combination of small drawn beads and larger wound beads (Merck 1980:78). Sarychev (1806:8-9) noted that "the front of the dress, and the opening of the arms, is trimmed with a row of pearls or coral. Their festival dress is similar in shape, but more enamelled, and bordered with rows of corals, bird's beaks, and goat's hair."

Thus, it appears that the most decorated clothing was saved for celebratory occasions. Merck (1980:79) also wrote that women wore more elaborate parkas on such occasions. The beaded decoration on these parkas was reported to consist of colored designs, mostly blue, on a white ground (Merck 1980:78). Women also used beads in jewelry worn around the neck, at the wrists, and in labrets, earrings, and nasal septum piercings (Coxe 1780:257; von Langsdorff 1993:17). Merck (1980:79) mentioned beads worn in a circular design at the ears and hung from a piece of bone in the nose. Billings, (in Titova 1980:201) also reported women wearing "a multitude of decorations, two or three rows of such beads under the ears." Women of common and slave ranks may have owned very little beaded clothing, or none at all. Francis (1994:293) noted that "beads could be socially valuable," and an Unalaskan woman who acquired a large number of beads "became an object of universal envy among her female countrywomen, and was esteemed the richest of all the inhabitants" (Sarychev 1806:39). Overall, the availability of beads to Alaska-bound traders, the relationship of Alaska Natives to European colonists, and Alaska Native tastes and needs influenced the different types of beads that reached the Reese Bay longhouse.

\section{Glass Beads in the Reese Bay Longhouse}

Original cultural processes, post-depositional factors, and archaeological recovery techniques affect the spatial and chronological distribution of the beads. The representativeness of the bead sample from the longhouse will be discussed before the paper turns to the interpretation of the collection.

\section{Recovery Rates and Confounding Factors}

The complete Reese Bay bead assemblage consists of approximately 3,200 beads. However, due to incomplete records involving nearly 1,000 of the beads (important information concerning color, size, and type is missing), approximately one-third of the bead collection was excluded from this analysis. These excluded beads are missing and are not currently available for examination, and while there is provenience information available for these missing beads, there is no descriptive information. The missing beads come from a variety of spatial contexts and there does not appear to be any determining factor or pattern to the missing group. Thus, we suggest that the 2,266 beads with complete records likely provide a representative sample of the whole. The composition of the bead assemblage used in this analysis-the 2,266 beads-is represented in Table 2 . 
Table 2. Composition of the Reese Bay glass trade bead assemblage by bead type.

\begin{tabular}{llllllll}
\hline & $\begin{array}{l}\text { Small } \\
\text { White } \\
\text { Drawn }\end{array}$ & $\begin{array}{l}\text { Small } \\
\text { Blue } \\
\text { Drawn }\end{array}$ & $\begin{array}{l}\text { Cornaline } \\
\text { d'Aleppo* }\end{array}$ & $\begin{array}{l}\text { Other } \\
\text { Small } \\
\text { Drawn }\end{array}$ & $\begin{array}{l}\text { Large } \\
\text { Wound }\end{array}$ & $\begin{array}{l}\text { Large } \\
\text { Wound \& } \\
\text { Molded }\end{array}$ & Total \\
\hline $\begin{array}{l}\text { Number } \\
\text { Recovered }\end{array}$ & 1,107 & 764 & 183 & 93 & 115 & 4 & 2,266 \\
$\begin{array}{l}\text { Percentage } \\
\text { of Total }\end{array}$ & $48.9 \%$ & $33.7 \%$ & $8.1 \%$ & $4.1 \%$ & $4.9 \%$ & $0.2 \%$ & $100 \%$ \\
\hline
\end{tabular}

\footnotetext{
*red over green or clear, small drawn type
}

It is important to ascertain how recovery rates affected the size and composition of the bead ¿̊ assemblage. In 1988, 1989, and 1990 the longhouse was excavated in $1 \mathrm{~m}^{2}$ units, and only the northwest quadrant $\left(50 \mathrm{~cm}^{2}\right)$ was water-screened othrough $1 / 16^{\prime \prime}$ mesh. One might expect that the northwest (water-screened) quadrant would proธิ่ duce proportionally more small or dark beads than $\checkmark$ would the other three quadrants because recovery of these difficult-to-see beads would be enhanced by the water-screening. Small beads are defined here as those less than $5 \mathrm{~mm}$ in diameter, while $\overrightarrow{\mathrm{s}}$ large beads are greater than $5 \mathrm{~mm}$ in diameter. $\bar{\sigma}_{0}$ This effectively distinguishes wound from drawn

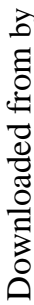

beads, as no wound bead was smaller than $5 \mathrm{~mm}$ and no drawn bead larger. No beads smaller than 2 $\mathrm{mm}$ in diameter were recovered from the Reese Bay longhouse.

Figure 3 shows the distribution of beads in the four quadrants. Small beads were somewhat less likely to be found in non-water-screened units than in units in the northwest quadrant, but the difference was not great. Bead color was distributed in very similar proportions across all quadrants. In other words, the northwest quadrant contained more beads of each color, but not a greater variety or proportion of dark colored beads, with one exception. No green beads were recovered

\section{Bead Types by Quadrant}

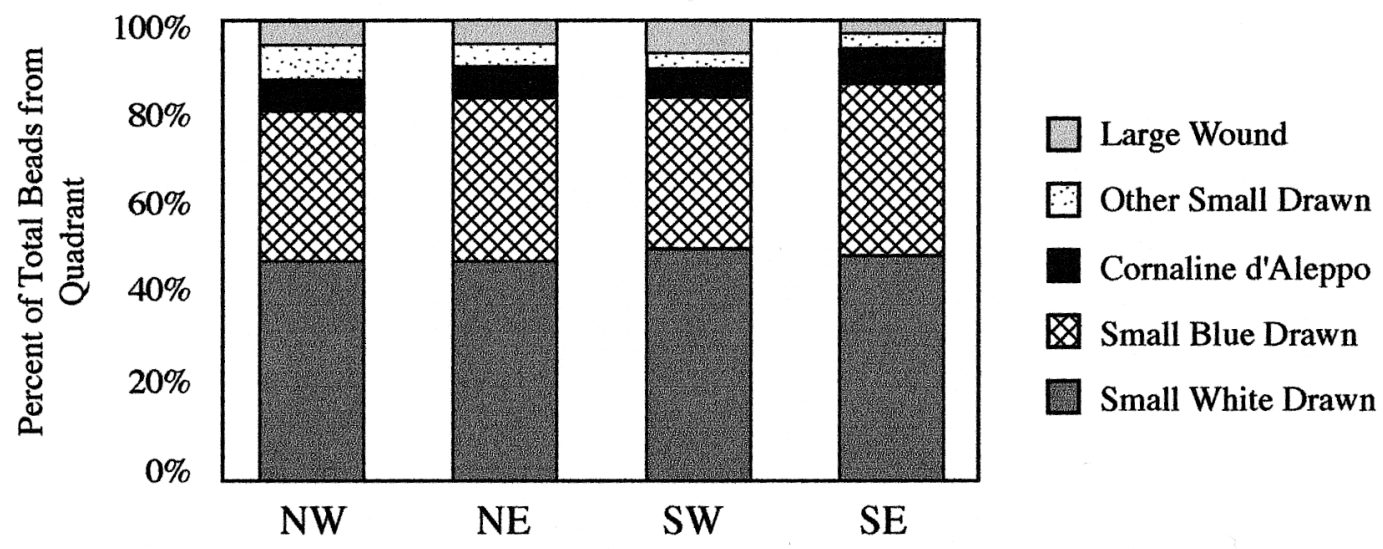

Figure 3. Bead distribution by type and quadrant. Northwest quadrants were waterscreened, others were not. 
from non-water-screened quadrants, but very few green beads were recovered in general. This may be due to the rarity of green beads in the site rather than recovery methods. Thus, water screening appears to improve bead recovery rates, but not affect the sizes and colors of beads recovered.

Nine-hundred forty-one beads were recovered from the northwest quadrant, compared to 348,386 , and 364 from the northeast, southwest, and southeast quadrants, respectively (for 222 beads, the quadrant was not recorded). Thus, water-screening resulted in the recovery of almost three times as many beads on average. Even when water-screening was employed, an unknown number of beads were likely missed by excavators. However, it is encouraging that the proportions of bead size and color are relatively constant across quå․․rants, as this suggests that the Reese Bay collection is an adequate sample with which to make a dẹtailed comparison of bead types.

ÖPost-depositional cultural activities might have affected the composition and patterning of the d्dissemblage. The superstructure of the longhouse was probably dismantled and the major suptorts reused after abandonment (Mooney 199 house floor. If activities had been conducted on the woof prior to its removal, artifacts on the roof wolkd have fallen onto the house floor during the dis通antling process as well. Finally, periodic hou否e cleaning during occupation almost certainly affeêted artifact distribution. With these caveats in mingl, the aspects of the bead assemblage of possi-

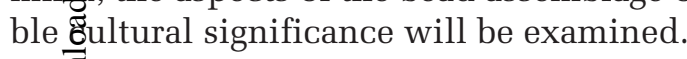

\section{Cuffural Factors: Assemblage Composition}

Ethnographic accounts describe a certain pattern of bead use. Based on these accounts, bead color, size, and type are considered important variables. Further, descriptions of bead use lead to the expectation that the small, white, drawn beads that were used as background color on extensively decorated women's clothing would dominate the assemblage. Small, colored, drawn beads would be represented in somewhat lower numbers, as would the large wound beads that were used more sparingly.

The composition of the bead collection essentially fits the expected pattern. White drawn beads dominate the collection. Together the small white and blue drawn beads make up $82.6 \%$ of the total. Only $5 \%$ of the beads were wound beads larger than $5.0 \mathrm{~mm}$ in diameter, which is consistent with historic accounts of bead trade and use.

\section{Cultural Factors: Chronology and Seriation}

Crowell $(1994,1997)$ used physical characteristics of bead collections to develop a seriation chronology for the Alaskan bead trade, part of which is shown in Figure 4. The 495 trade beads from the 1986 testing were used to place Reese Bay in the chronology (Crowell 1994:298). The Reese Bay trade bead proportions were, however, recalculated using the entire bead collection. Figure 5 shows the 1986 data, which were collected by Peter Francis, compared to the data from subsequent seasons. The compositions of the assemblages are very similar. Even with the addition of more than 2,200 beads, the proportions used by Crowell remain essentially the same. Crowell's table suggests that an early assemblage would lack cornaline d'Aleppos with white centers, seed beads (small beads less than $2 \mathrm{~mm}$ in diameter), and faceted wound beads (often called "Russian beads"). None of these bead types appear in the Reese Bay collection. The comparative data from other Alaskan sites indicate that the historical occupation of Reese Bay was very early.

The vertical distribution of beads for all units supports the idea that the earliest occupation of the site was late prehistoric (Table 3). For the most part, the longhouse was excavated in arbitrary 5 $\mathrm{cm}$ and $10 \mathrm{~cm}$ levels. The top $10 \mathrm{~cm}$ of the excavation included an approximately $5 \mathrm{~cm}$ deep sod layer, and it contained over 500 beads. This top layer could contain significant debris from the dismantling of the superstructure of the longhouse (Mooney 1993). The second level contained the most beads, over 800, and succeeding levels contained fewer and fewer. The lowest two levels of excavation were devoid of trade beads. These earliest levels did not yield objects of European origin. The large concentration of beads and other historic artifacts in the second stratum relative to the first supports the reports of significantly fewer people living in the longhouse in the last years of its occupation. It could also indicate a declining demand for beads or a declining bead supply.

If bead preference and supply changed very quickly, these changes might be reflected stratigraphically. Changes in the Reese Bay assemblage could provide a basis for a more specific trade bead chronology in the early Russian period. However, analyses revealed that bead proportions hardly varied with stratigraphic level. Wound bead proportions were very consistent throughout the deposit, with the exception of three "raspberry" type beads that were found in the upper- 


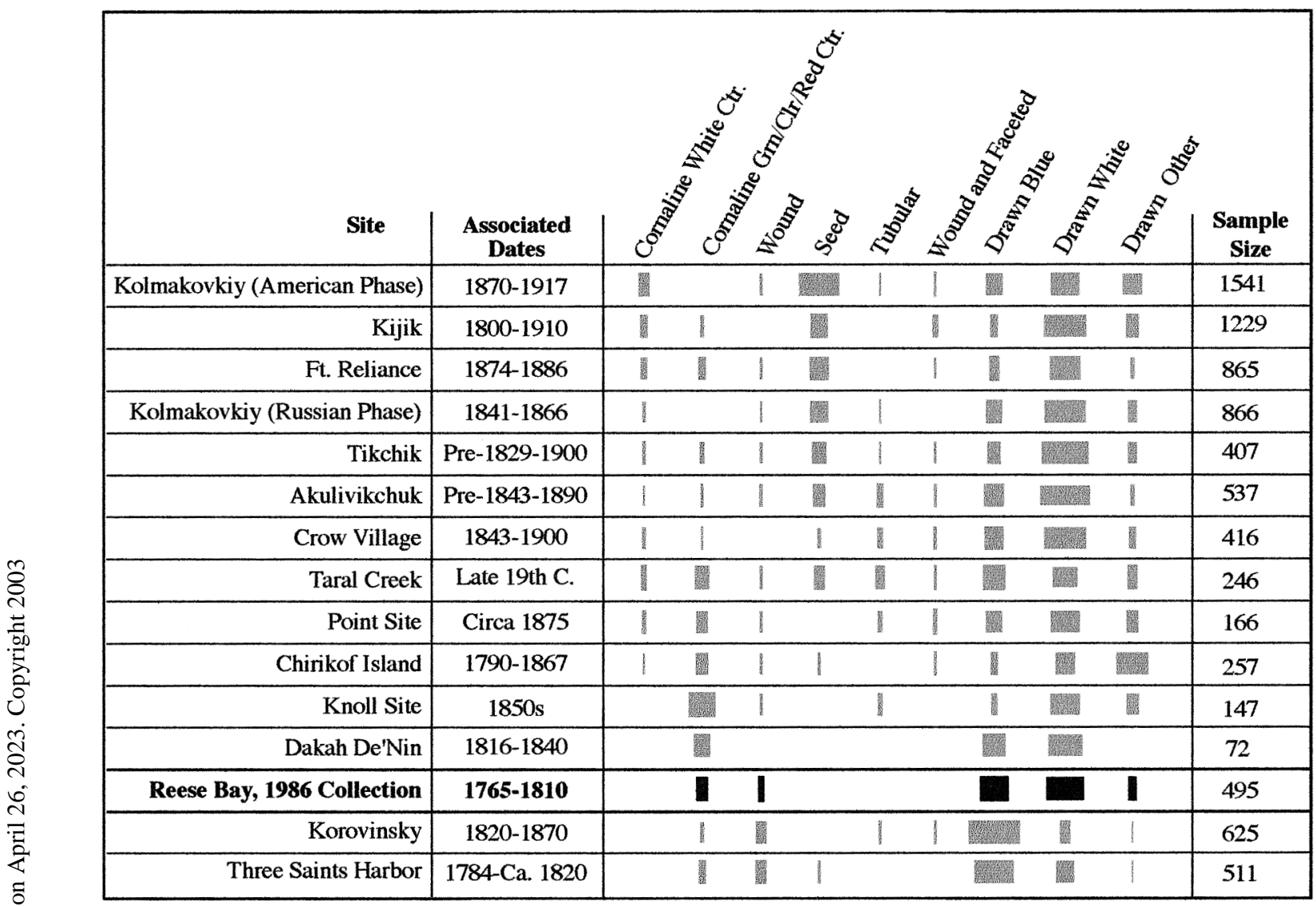

Figure 4. Glass trade bead seriation chart, modified from Crowell (1997:176).

है

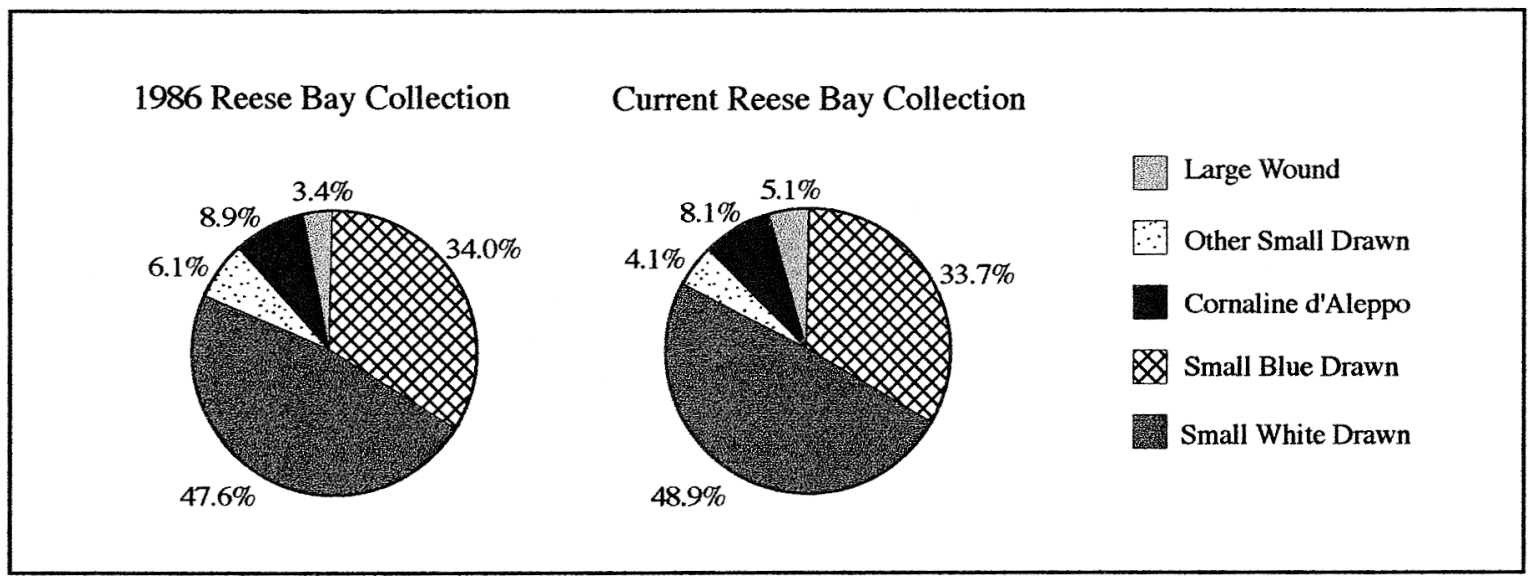

Figure 5. Trade bead assemblage composition. The first chart represents the beads collected in 1986 that were used by Crowell in the 1997 seriation; the second chart represents the beads in the current collection.

most $10 \mathrm{~cm}$ level in one unit. The proportions of different colors and types of small drawn beads also showed little change (Fig. 6). The composition of the bead assemblage by color and type remained very consistent throughout the contact-era occupation. The Reese Bay longhouse floor showed very little vertical stratification. Both the homogenous assemblage composition and the single floor suggest that occupation of Longhouse 2 may have been relatively short. 
Table 3. Beads and other artifacts of European origin by stratigraphic depth (below surface).

\begin{tabular}{|c|c|c|}
\hline $\begin{array}{l}\text { Depth below } \\
\text { surface }\end{array}$ & $\begin{array}{l}\text { Number of trade } \\
\text { beads* }\end{array}$ & $\begin{array}{l}\text { Number of other objects } \\
\text { of European origin }\end{array}$ \\
\hline $0-10 \mathrm{~cm}$ & 550 & 42 \\
\hline $10-20 \mathrm{~cm}$ & 837 & 95 \\
\hline $20-30 \mathrm{~cm}$ & 518 & 33 \\
\hline $30-40 \mathrm{~cm}$ & 199 & 11 \\
\hline $40-50 \mathrm{~cm}$ & 100 & 9 \\
\hline $50-60 \mathrm{~cm}$ & 14 & 3 \\
\hline $60-70 \mathrm{~cm}$ & 0 & 0 \\
\hline $70-80 \mathrm{~cm}$ & 0 & 0 \\
\hline Totạ్ & 2,218 & 193 \\
\hline
\end{tabular}

${ }^{*}$ Fo 48 of the 2,266 beads, depth was not included in provenience information. Those beads are not listed herêे
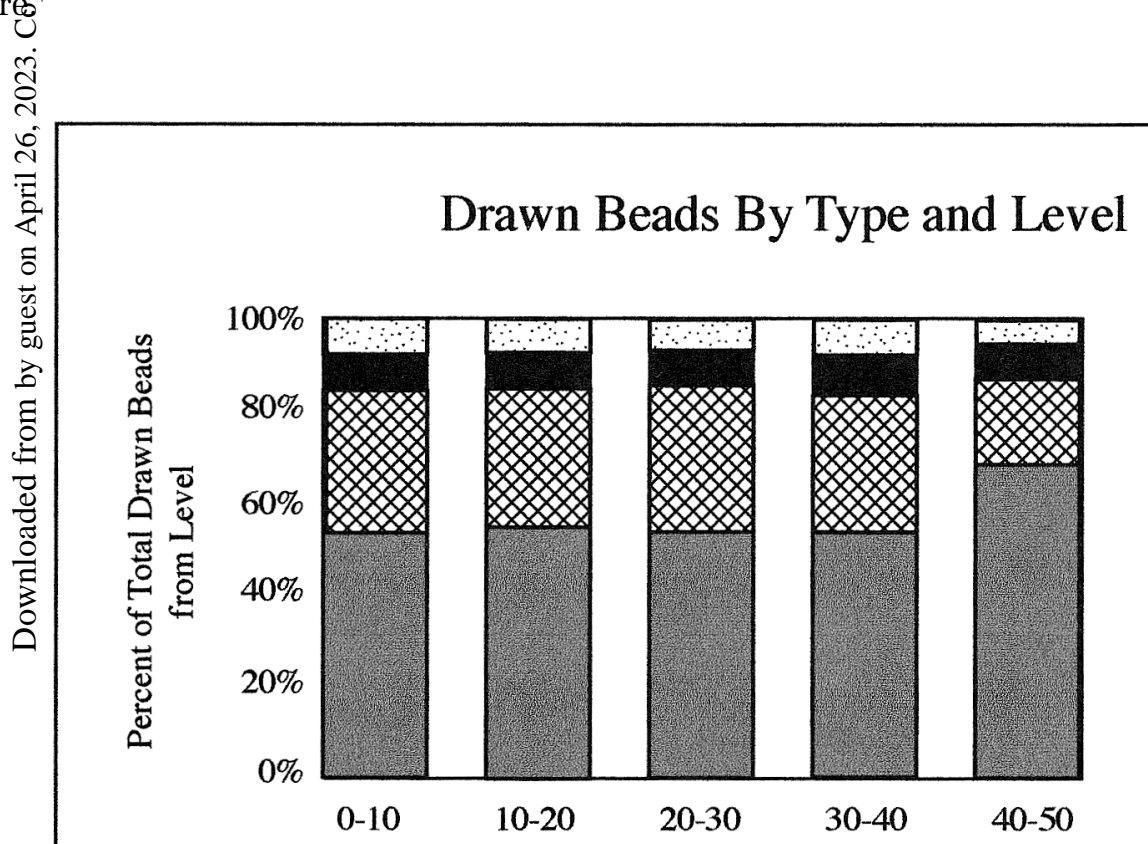

Other Small Drawn

Cornaline d'Aleppo

Small Blue Drawn

Small White Drawn

Centimeters Below Surface

Figure 6. Vertical distribution of drawn beads.

\section{Cultural Factors: Spatial Patterning}

Ethnographic information suggests that horizontal bead distribution might vary based on four main behavioral factors: status differentiation (and thus unequal access to trade goods) along the east-west axis of the longhouse; burial practices; side room usage; and patterns of bead loss. The horizontal distribution of beads from the Reese Bay longhouse (Fig. 7) is compared to expected patterns based on these four factors.

In order to conduct a distributional analysis, the longhouse was divided in several ways. First, bead distribution in side rooms (ancillary depressions) was compared to the distribution in the 


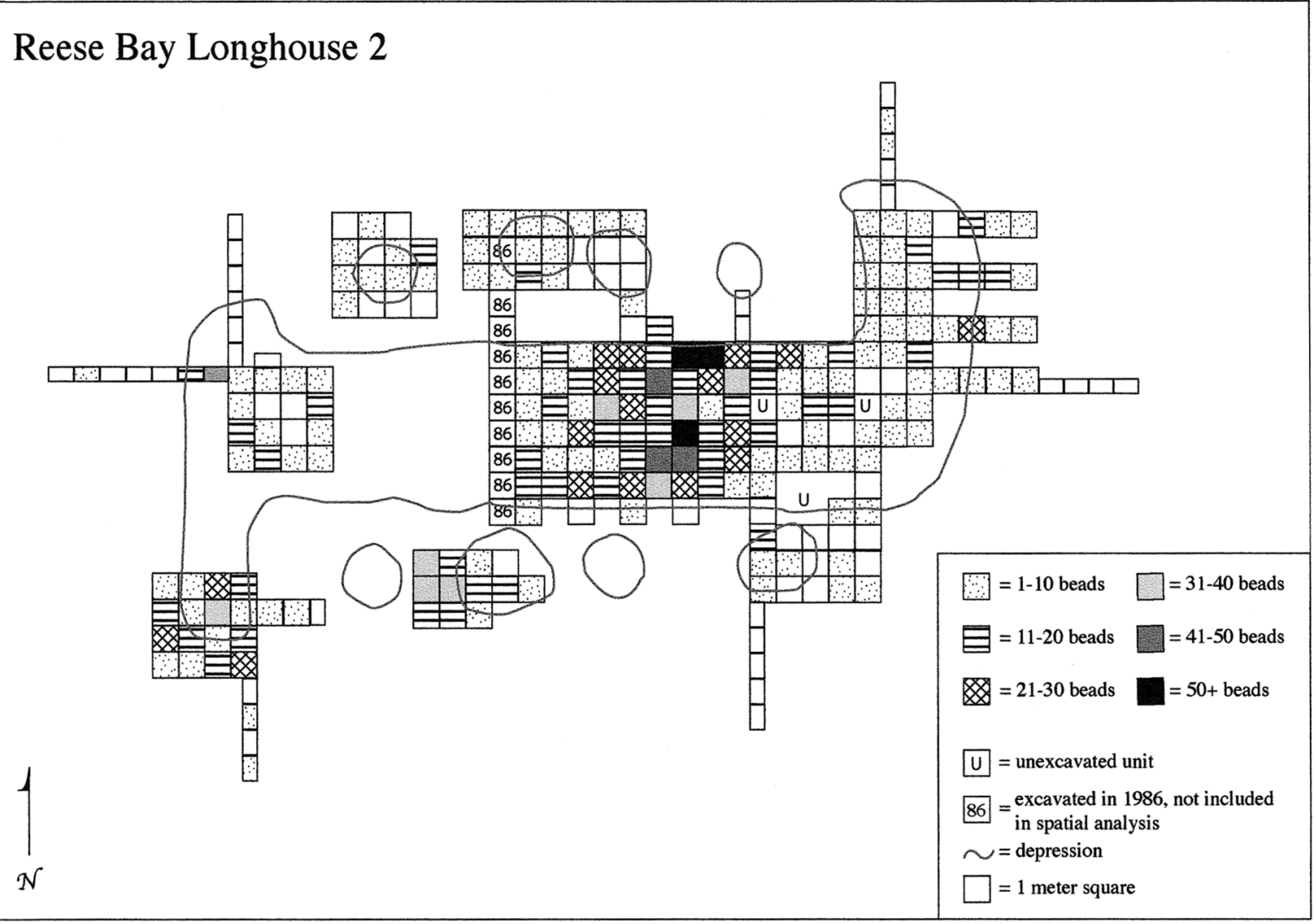

Figure 7. Horizontal distribution of beads in Longhouse 2.

main area of the longhouse. Second, units associated with human burials were compared to all other units. Third, distribution of beads of different sizes and types was compared across all units. There were 263 separate units excavated at the longhouse, 25 of which were $1 \mathrm{~m} \times 50 \mathrm{~cm}$ units in test trenches. The remaining units were $1 \mathrm{~m}^{2}$. Bead data are available for only 252 units (all $1 \mathrm{~m}^{2}$ ) because provenience data for the 1986 excavations is not in the database at this time.

There are several status-related issues that might affect bead distribution. If toions and their immediate families were maintaining control of the bead trade, one would expect a concentration of beads (or certain types of beads) at the east end of the longhouse. On the other hand, if women and/or low-ranking men became middlemen or brokers of European goods, traditional hierarchical relationships may have been undermined. This could result in a more even distribution of beads across areas of the longhouse. However, because Unangan socio-economic organization involved redistribution, an absence of bead concentrations does not in itself prove that traditional social organization was disrupted.

Based on the current collection of beads, it is unclear whether differentiation along the east-west axis exists. The longhouse runs from approximately $100 \mathrm{~m}$ east to $130 \mathrm{~m}$ east on the site grid. The eastern half of the central floor did contain the largest concentrations of beads. Since so little of the western half of the central floor was excavated, however, it is impossible to say whether the bead concentration in the east-central area is the result of more beads in the eastern part of the longhouse, or the result of a concentration of beads in the central floor area in general.

Another factor that could have affected bead distribution is the burial of the dead with beads or in beaded clothing and jewelry. Beads are commonly found in burials across North America. The three burial areas in the longhouse were near (within 2-3 m) bead concentrations. Except for the burial in the west trench, however, none were close enough to have been the clear result of burial inclusions. 
If side rooms were used as storage areas, perhaps beads would be concentrated there until they were used. Other than side room G, the rooms had lower concentrations of beads than the main house floor. It is possible that side room $\mathrm{G}$ was used for bead storage. However, given the relative scarcity of beads in the other side rooms, and the lack of authoritative ethnographic references to side room usage, this is only speculative.

Bead loss patterns provide the best explanation for the distribution data. Bead loss may have been significant when bead-working activities were taking place. Mooney (1993) suggested that a concentration of beads near the center of the longhouse resulted from bead working in the area of greatest available light; that is, under an entrance ladder suspended from the roof. This is als@्ळ of course, an area of high traffic. Bead concenfrations also seem to occur along the northern and 50 outhern borders of the central longhouse flooक्ष, in the trench areas reported to be family living and work space. It is possible that people spe@t more time in the family areas, and the distribj్tion reflects the fact that more beads were losfrom clothing and jewelry at those locations tharin other parts of the house. The pattern might also reflect bead-working activity in those areas. Other bead concentrations, in side room G and maloufacturing areas where numbers of beads werf lost. No needles were found at the Reese Bay $=$ site to corroborate that sewing was taking plagese in these areas.

OIn two cases, beads were clearly associated wit each other. Four large amber-colored beads and three "raspberry" beads (large wound beads with a scored surface) were found in the first stratum of one unit in the middle of the longhouse. In both cases, these beads represent the majority of both those types. In the adjacent unit, six large white wound beads were found in a row in the second stratum. These two units are near, but not clearly associated with, a burial and also contain relatively large numbers of beads overall (45 and 30 , respectively), perhaps indicating that two individual beaded items were lost or discarded in the area.

Altogether, the horizontal distribution of the glass trade beads is somewhat inconclusive with regard to specific behaviors reported ethnographically. Mixed results were obtained from the typological and distributional analyses of the glass trade bead collection from Longhouse 2 at the Reese Bay site. The bead types and their vertical distribution confirm that the longhouse was occupied in the late prehistoric and very early historic periods. However, the horizontal distribution of the beads proved difficult to interpret.

\section{Summary and Conclusions}

Glass trade beads are one of the most ubiquitous and useful artifacts in historic North American sites. Like ceramics, beads preserve well, were highly desired by many Native groups, and are time diagnostic to an extent. Unlike ceramics, beads carry no maker's marks. It can be difficult to trace the origins and routing of glass beads bound for North America. Some researchers are now employing chemical analyses to source glass (Crowell 1994, 1997) and hopefully in the future these techniques will improve provenance studies. Nonetheless, bead research is still relevant to many other avenues of inquiry, especially for the early Russian contact period in Alaska.

Beads are an important component of the Reese Bay assemblage, making up over $90 \%$ of the historical artifacts in Longhouse 2 at the site. The assortment of bead types in the collection is consistent with early reports of bead preferences and use. This information provides an independent line of evidence by which to evaluate the observations of early European visitors. Also, the characteristics of the bead collection are consistent with a very early historical occupation. The concentration of historical artifacts in the second stratigraphic level of the site, and the lack of those artifacts past $60 \mathrm{~cm}$ below the surface, corroborate the early date.

In addition to their utility for those interested in the chronology of the early Russian contact period in the Aleutians, beads also represent the end product of a complex relationship between cultures. Russia was fighting for a foothold in the Pacific that would fill the state coffers and provide the country the respectability a colonial power commanded in eighteenth century Europe. Individual Russian promyshlenniki sought wealth and the less tangible status denied them in their home country. Unangan people were involved in their own status hierarchy, one that may have been disturbed by the introduction of trade goods. Social structure and relationships were also affected by depopulation, warfare with Russians, and forced sea mammal hunting.

Glass trade beads were a means to an end for both Russians and Alaska Natives. For promyshlenniki, procurement of the furs they wanted required the expertise of Unangan sea mammal hunters. En- 
listing those hunters alternately (and concurrently) involved enticement, coercion, and outright force. Unangan people actively sought beads of certain kinds to be used in personal ornamentation. The use of beads was reflected to a limited (and somewhat speculative) extent in the horizontal distribution of the beads. The distribution of the beads may have been created and affected by several factors, both behavioral and depositional: roof fall from the dismantling of the longhouse superstructure; periodic housecleaning by the residents of Longhouse 2 ; bead working techniques and bead working areas; changing status relationships within the longhouse; or a mistaken perception of status/location arrangements by Veniaminov. Data from Reese Bay provide insight into the chronology and nature of occupation at the site. While beads are often only a $\overbrace{\text { }}$ small part of the information recovered during an Excavation, they can provide a wealth of information about the inhabitants of the site, international ofexchange, and sociopolitical transformations in the contact period.

ฮิ

Acknowledgments. The Reese Bay study, part of the Unalaska Archaeology and History Project, was funded by the National Science Foundation (8806802), the National Endowment for the Huof manities (RO 21690-88), the National Geographic of Society, the Alaska Humanities Forum, the Univer${ }^{\mathrm{D}}$ sity of Alaska, and the Aleut Corporation. Allen McCartney and Douglas Veltre, along with Drs. Jean Aigner and Lydia Black, served as co-principal investigators for the Reese Bay project. The University of Arkansas, Peninsula Airways, Reeve Aleutian Airways, MarkAir, and Northern Air Cargo provided valuable in-kind support. The Ounalashka Corporation generously provided inkind support and permission to investigate the site. Finally, the fieldwork would not have been possible or enjoyable without the enthusiastic assistance of numerous residents of Unalaska and the 35 field crew members who worked at Reese Bay between 1986 and 1990. The authors also wish to thank Susan Kaplan, Jon Erlandson, Scott Fitzpatrick and an anonymous reviewer for thoughtful comments that have substantially improved this paper.

\section{References Cited}

Beaglehole, J. C.

1967 The Journal of Captain James Cook on His Voyage of Discovery, 3(2). Cambridge: Cambridge University Press.

Berkh, Vasilii N.

[1823] A Chronological History of the Discovery of the 1974 Aleutian Islands. Ontario: The Limestone Press.
Black, Lydia T.

1988 The Story of Russian America. In Crossroads of Continents. W. Fitzhugh and A. Crowell, eds. Pp. 70-82. Washington, D.C.: Smithsonian Institution Press.

1991 Unalaska Archaeology and History Project. National Geographic Research and Exploration 7(4):490-497.

Black, Lydia T. and R. G. Liapunova

1988 Aleut: Islanders of the North Pacific. In Crossroads of Continents. W. Fitzhugh and A. Crowell, eds. Pp. 52-57. Washington, D.C.: Smithsonian Institution Press.

Bundy, Barbara E.

1998 Glass Trade Beads from Reese Bay, Unalaska Island. Master's thesis, Department of Anthropology, University of Arkansas.

Coxe, William

1780 The Russian Discoveries between Asia and America. March of America Facsimile Series Reprint 1966. Ann Arbor: University Microfilms.

Crowell, Aron L.

1994 World Systems Archaeology at Three Saints Harbor, an Eighteenth Century Russian Fur Trading Site on Kodiak Island, Alaska. Ph.D. dissertation, Department of Anthropology, University of California at Berkeley.

1997 Archaeology and the Capitalist World System. A Study from Russian America. New York: Plenum Press.

Dmytryshyn, B., E. A. P. Crownhart-Vaughn, and T. Vaughn

1988 Introduction. In Russian Penetration of the North Pacific Ocean. B. Dmytryshyn, E. A. P Crownhart-Vaughn, and T. Vaughn, eds. Pp. xxxi-lxxxiii. Portland: Oregon Historical Society Press.

Francis, Peter Jr.

1988 Report on the beads from Reese Bay, Unalaska. Ornament, Autumn.

1994 Beads at the Crossroads of Continents. In Anthropology of the North Pacific Rim. W.

Fitzhugh and V. Chaussonet, eds. Pp. 281-305. Washington, D.C.: Smithsonian Institution Press.

Gibson, James R.

1969 Feeding the Russian Fur Trade. Madison: University of Wisconsin Press.

1976 Imperial Russia in Frontier America. New York: Oxford University Press.

1990 Furs and Food: Russian America and the Hudson Bay Company. In Russian America: The Forgotten Frontier. B. S. Smith and R. J. Barnett, eds. Pp. 41-54. Tacoma: Washington Historical Society. 
Graeber, David

1996 Beads and Money: Notes toward a Theory of Wealth and Power. American Ethnologist 23(1):4-24.

Grumet, Robert S.

1995 Historic Contact: Indian People and Colonists in Today's Northeastern United States in the Sixteenth through Eighteenth Centuries. Norman: University of Oklahoma Press.

Inter-Society Color Council (ISCC) and National Bureau of Standards (NBS)

1955 ISCC-NBS Color-Name Charts Illustrated with Centroid Colors. (Supplement to NBS circular 533, The ISCC-NBS Method of Designating Color and a Dictionary of Color Names). Washington, D.C.: U.S. Government Printing Office.

Jochelson, Vladimir I.

1933 History, Ethnology, and Anthropology of the

$\%$ Aleut. Washington, D.C.: Carnegie Institute of

\& Washington Publication, no. 432.

Kar䚙ins, Karlis

198管 Guide to the Description and Classification of Glass Beads. History and Archaeology, no. 59, National Historic Parks and Sites Branch, Parks ชิ่ Canada, Ottawa.

Khlonikov, Kiril Timofeevich

1994 Notes on Russian America, Parts II-V: Kadiak, Unalashka, Atkha, the Pribylovs. Ontario: The

๘ Limestone Press.

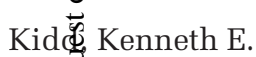

$197 \Phi^{\circ}$ Glass Bead Making from the Middle Ages to the Early Nineteenth Century. History and Archaeology, no. 30, Parks Canada, Ottawa.

Kid产 Kenneth E. and Martha Ann Kidd

197@ A Classification System for Glass Beads for the Use of Field Archaeologists. Canadian Historic Sites, Occasional Papers in Anthropology and History, no. 1, Ottawa.

Lantis, Margaret

1984 Aleut. In Handbook of North American Indians, vol. 5, Arctic. David Damas, ed. Pp. 161-184.

Washington, D.C.: Smithsonian Institution Press.

Laughlin, William S.

1980 Aleuts: Survivors of the Bering Land Bridge. Ft. Worth: Holt, Rinehart, and Winston.

Laughlin, William S. and Jean S. Aigner

1975 Aleut Adaptation and Evolution. In Prehistoric Maritime Adaptations of the Circumpolar Zone. W. Fitzhugh, ed. Pp. 181-202. Paris: Mouton.

Liapunova, Roza G.

1996 Essays on the Ethnography of the Aleuts (at the End of the Eighteenth and the First Half of the Nineteenth Century). Fairbanks: University of Alaska Press.

McCartney, Allen P.

1984 Prehistory of the Aleutian region. In Handbook of North American Indians, vol. 5., Arctic.
David Damas, ed. Pp. 119-135. Washington, D.C.: Smithsonian Institution Press.

McCartney, Allen P. and Douglas W. Veltre

1999 Aleutian Islands Prehistory: Living in Insular Extremes. World Archaeology 30(3):503-516.

In Longhouses of the Eastern Aleutian Islands,

press Alaska. In To the Aleutians and Beyond: The Anthropology of William S. Laughlin. B. Frohlich, A. B. Harper, and R. Gilberg, eds. Publications of the National Museum, Ethnographical Series, vol. 20. Copenhagen: Department of Ethnography, The National Museum of Denmark.

McCartney, Allen P., Douglas W. Veltre, Jean A. Aigner, and Lydia T. Black

1988 Preliminary Report of Research Conducted by the Unalaska Archaeology and History Project during 1988. Report submitted to the National Science Foundation.

1990 Unalaska Archaeology and History Project Preliminary Report of Operations 1989. Report submitted to the National Endowment for the Humanities.

Makarova, R. V.

1975 Russians on the Pacific 1743-1799. Ontario: The Limestone Press.

Merck, Carl Heinrich

[1788- Siberia and Northwestern America 1788-1792:

1792] The Journal of Carl Heinrich Merck, Naturalist

1980 with the Russian Scientific Expedition Led by Captains Joseph Billings and Gavriil Sarychev. Ontario: The Limestone Press.

Miller, Polly G.

1994 Early Contact Glass Trade Beads in Alaska. Altamonte Springs: The Bead Society of Central Florida.

Mitchem, Jeffrey M. and Jonathan M. Leader

1988 Early 16th Century Beads from the Tatham Mound, Citrus County, Florida: Data and Interpretations. The Florida Anthropologist 41(1):42-60.

Mooney, James P.

1993 An Eighteenth Century Aleutian Longhouse at Reese Bay, Unalaska Island. Master's thesis, Department of Anthropology, University of Arkansas.

Murie, Olaus J.

1959 Fauna of the Aleutian Islands and Alaska Peninsula. United States Department of the Interior North American Fauna Series, no. 61.

Ozhegov, S. I.

1989 Slovar’ Russkogo Yazuika. Moskva: Russkii Yazuik.

Pagden, Anthony

1995 Lords of All the World: Ideologies of Empire in Spain, Britain, and France c.1500-1800. New Haven: Yale University Press. 
Pielou, E. C.

1991 After the Ice Age: The Return of Life to Glaciated North America. Chicago: University of Chicago Press.

Rollings, Willard H.

1992 The Osage: An Ethnohistory of Hegemony on the Prairie Plains. Columbia: University of Missouri Press.

Sarychev, Gavriil Andreyevich

1806 Account of a Voyage of Discovery to the NorthEast of Siberia, the Frozen Ocean, and the North-East Sea. London: Richard Phillips.

Scott, Vanya R.

1990 A Preliminary Analysis of Reese Bay Trade Beads, Northwest Quadrant, 1989 Season. Unpublished undergraduate paper for Anthropology 480. On file with Dr. Douglas Veltre, Department of Anthropology, University of Alaska Anchorage.

Shelikov, Grigorii I.

1980 A Voyage to America 1783-1786, translated by M. Ramsay. R. A. Pierce, ed. Ontario: The Limestone Press.

Spector, Janet D.

ป1976 The Interpretive Potential of Glass Trade Beads in Historic Archaeology. Historical Archaeology 10:17-27.

Sprague, Roderick

$\Xi_{0} 1985$ Glass Trade Beads: A Progress Report. Historical ㅎํ Archaeology 19(2):87-105.

Stone, Lyle

$\Xi 1970$ Archaeological Research at Fort Michilimackinac, an Eighteenth Century Historic Site in Emmett County, Michigan, 1959-1966 Excavations. Ph.D. dissertation, Department of Anthropology, Michigan State University.
Titova, Z. D.

1980 Voyage of Mr. Billings from Okhotsk to Kamchatka; his arrival there; setting out for the American Islands; return to Kamchatka; second sea voyage to those islands from the north; thence to Bering Strait and Chukotskii, nos., 17891790-1791. From Etnograficheskie materialy Severo-Vostochnoi Geograficheskoi Ekspeditsii. 1785-1795. Extract from original manuscript published in Siberia and Northwestern America 1788-1792: The Journal of Carl Heinrich Merck, Naturalist with the Russian Scientific Expedition Led by Captains Joseph Billings and Gavriil Sarychev. Ontario: The Limestone Press.

van Der Sleen, W. G. N.

1973 A Handbook on Beads. York: Liberty Cap Books.

Veltre, Douglas W.

1990 Perspectives on Aleut Culture Change during the Russian Period. In Russian America: The Forgotten Frontier. B. S. Smith and R. J. Barnett, eds.

Pp. 175-83. Tacoma: Washington Historical Society.

Veltre, Douglas W. and Allen P. McCartney

2001 Ethnohistorical Archaeology at the Reese Bay Site, Unalaska Island. In Archaeology of the Aleut Zone of Alaska, D. Dumond, ed. Pp. 87-104. University of Oregon Anthropological Papers no. 58, Eugene: University of Oregon.

Veniaminov, Ivan

[1940] Notes on the Islands of the Unalashka District.

1984 L. T. Black and R. H. Geoghegan, trans. Ontario: The Limestone Press.

von Langsdorff, Georg Heinrich

1993 Remarks and Observations on a Voyage Around the World from 1803-1807, Volume 1. Ontario: The Limestone Press.

Woodward, Arthur

1989 Indian Trade Goods. Portland: Binford and Mort. 